\title{
Primary and bacterial productivity of tropical seagrass communities in the Gulf of Carpentaria, Australia
}

\author{
D. J. W. Moriarty, D. G. Roberts*, P. C. Pollard \\ CSIRO Marine Laboratories, PO Box 120, Cleveland, Queensland 4163, Australia
}

\begin{abstract}
Plant and bacterial productivities were compared at different seasons in 3 communities of seagrass in the Gulf of Carpentaria, Australia, in 1985. Seagrass biomass and shoot density were very variable, with no seasonal trend. The gross primary productivity of the seagrasses in each of the communities (Syringodium isoetifolium with Cymodocea serrulata in a bay, Halodule uninervis at a river mouth, and Thalassia hemprichii with Cymodocea rotundata on a reef flat) were determined seasonally from rates of lacunal gas production. Productivity varied seasonally, being lowest in winter (July). Values ranged from 0.6 to $1.0 \mathrm{~g} \mathrm{C} \mathrm{m}^{-2} \mathrm{~d}^{-1}$ for C. serrulata, 0.3 to 8.1 for S. isoetifolium, 0.9 to 3.5 for $H$. uninervis, 0.2 to 0.4 for $T$ hemprichii and 0.1 to 1.0 for C. rotundata. Gross community primary productivity, measured from diurnal changes in oxygen concentration in the water column, ranged from 3.3 in winter to $9.3 \mathrm{~g} \mathrm{C} \mathrm{m}^{-2} \mathrm{~d}^{-1}$ in summer at the bay site, 2.7 to 4 at the river mouth and 3.3 to 8.4 on the reef flat. Bacterial productivity was determined using the rate of tritiated thymidine incorporation into DNA. Most ( 90 to $95 \%$ ) bacterial biomass was produced in the sediment. Between winter and summer, total bacterial productivity (including water column) ranged from 1.0 to $4.8 \mathrm{~g} \mathrm{C} \mathrm{m}^{-2} \mathrm{~d}^{-1}$ in the bay, 0.6 to 2.5 at the river mouth and 0.6 to 3.7 on the reef flat. Bacterial productivity averaged $43 \%$ (range 10 to $90 \%$ ) of gross primary productivity, and thus would account for about half of the primary production if their growth efficiency were $50 \%$. Animals appeared to have an impact on bacteria at the sediment surface in summer, when specific growth rates and productivity were high, but numbers were low.
\end{abstract}

\section{INTRODUCTION}

In pelagic systems, zooplankton may graze at least $50 \%$ and up to $100 \%$ of primary production (Valiela 1984). In benthic coastal ecosystems with vascular plants, however, bacteria are the dominant consumers of primary production by the macrophytes, because most animals cannot digest the fibrous plant material, which also has a low protein content (Mann 1988). Thus where seagrasses are major primary producers, they may be important in marine food chains, but indirectly. Most animals that utilise seagrass production are dependent on decomposition and a detrital food chain or on epiphytic and benthic microalgae in seagrass beds (Moriarty 1976, Klug 1980, Morgan \& Kitting 1984). Quantitative studies on the cycling of carbon from primary producers through bacteria to

\footnotetext{
- Present address: School of Biological Sciences, University of Sydney, NSW 2006, Australia
}

animals have now become possible with the development of methods for quantifying bacterial production, based on the incorporation of thymidine into DNA. (Moriarty 1986). Bacterial productivity in temperate seagrass beds is linked to seagrass productivity (Moriarty \& Pollard 1982, Moriarty et al. 1985). It is difficult to determine the contribution of bacteria to carbon cycling and respiration in sediment in the presence of other organisms. With the thymidine method, one can estimate bacterial productivity, i.e. the rate at which new bacterial biomass is formed, and then calculate the rate of carbon cycling by bacteria if their growth efficiency is known.

Few studies have been made on productivity of seagrasses in the tropical Indo-Pacific region. Recently, however, seagrass beds in Papua New Guinea have been studied by Brouns $(1985,1987 a$, b) and Brouns \& Heijs (1986). Production averaged $6.4 \mathrm{~g}$ ash-free dry wt $\mathrm{m}^{-2} \mathrm{~d}^{-1}$ over a year, with little significant seasonal variation in a mixed seagrass bed of 6 species including 
the 5 that were studied in this report (Brouns 1987b). In Indonesia, Lindeboom \& Sandee (1989) reported that gross productivity of a Halodule uninervis community ranged from 2.5 to $4.1 \mathrm{~g} \mathrm{C} \mathrm{m}^{-2} \mathrm{~d}^{-1}$ and that of a Thalassia hemprichii community ranged from 1.2 to $4.7 \mathrm{~g} \mathrm{C} \mathrm{m}^{-2} \mathrm{~d}^{-1}$ in October Net productivity ranged from 0.06 to $1.1 \mathrm{~g} \mathrm{C} \mathrm{m}^{-2} \mathrm{~d}^{-1}$. Thus plant productivity in these tropical communities is high and we would expect bacterial productivity to be high also.

We selected 3 communities in the Gulf of Carpentaria, Australia, for studies on relationships between primary and bacterial productivity. The productivity of each community, and of seagrasses and bacteria in small sections of the communities, were studied to provide some insight into carbon cycling during each season, especially in the sediment.

\section{MATERIALS AND METHODS}

Study sites. The study sites were at Groote Eylandt, a continental island with similar geomorphology to the mainland nearby; the climate is monsoonal with rain occurring mostly between December and April (Fig. 1).

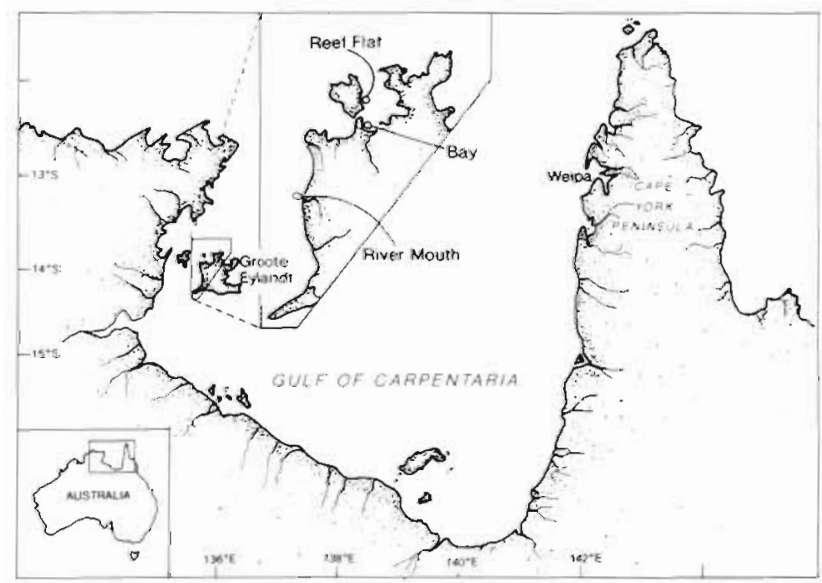

Fig. I Location of study sites at Groote Eylandt. Gulf of Carpentaria

The first sampling site was near a river mouth. It was a monospecific stand of Halodule uninervis (Forsk.) Aschers. in Bolssier on a sandy sediment in a community of $H$. uninervis and Halophila ovalis (R. Br.) Hook. F. inshore and Syringodium isoetifolium (Aschers.) Dandy and Cymodocea serrulata (R. Br.) Aschers. et Magnus offshore (site group E described by Poiner et al. 1987). The second sampling site was a bay with mostly $S$. isoetifolium and some $C$. serrulata on a silty clay sediment (site group F described by Poiner et al. 1987) There were no macroalgae present at that site. The third sampling site was a reef flat fringed on the landward side by mangroves and on the seaward side by a coral reef; macroalgae comprised a substantial proportion of plant biomass there. The seagrasses Thalassia hemprichii (Ehrenb.) Aschers. and Cymodocea rotundata Ehrenb. et Hempr. ex Ashers. were present (described by Poiner et al. [1987] as site group C). The sediment was a muddy silt with some coral rubble, 4 to $7 \mathrm{~cm}$ deep on a hard calcareous substrate. At each study site a net or cage of 4 to $6 \mathrm{~m}^{2}$, with a mesh of 80 to $100 \mathrm{~mm}$, was used to protect research workers from crocodiles and sharks.

Studies were carried out in January, May, July and October 1985. Water temperatures were: January, mean $32^{\circ} \mathrm{C}$, maximum $34^{\circ} \mathrm{C}\left(38^{\circ} \mathrm{C}\right.$ on the reef flat $)$; May, mean $30^{\circ} \mathrm{C}$, maximum $31^{\circ} \mathrm{C}$; July, mean $23^{\circ} \mathrm{C}$, maximum $24^{\circ} \mathrm{C}$ i October, mean $29^{\circ} \mathrm{C}$, maximum $33^{\circ} \mathrm{C}$. The highest temperatures occurred over the reef flat. The light intensity in the seagrass beds was measured with a submersible integrating light meter (Biospherical Instruments Inc., Model QSI-140). Maxima were $1500 \mu \mathrm{E} \mathrm{m}^{-2} \mathrm{~s}^{-1}$ at the river mouth and bay sites and 2000 at the reef flat in January; 1200 in May; 900 in July and 2400 in October. Day lengths (light intensity of $>200 \mu \mathrm{E} \mathrm{m}^{-2} \mathrm{~s}^{-1}$ ) were $11 \mathrm{~h}$ in January, $10 \mathrm{~h}$ in May, $9.7 \mathrm{~h}$ in July and $10.5 \mathrm{~h}$ in October.

All temperatures and oxygen concentrations in the water column and bottles were measured with a submersible electrode that produces oxygen at the same rate at which it is consumed, and therefore does not require the water to be stirred (Leeds and Northrup, Model 8500).

Biomass and shoot density. Six replicate cores $(10 \mathrm{~cm}$ diameter) of seagrass shoots, rhizomes, roots and sediments were collected to a depth of $12 \mathrm{~cm}$ at the first 2 sites and to the full depth of the reef flat ( 5 to $7 \mathrm{~cm}$ ). Shoots were counted and then the above-ground plant material was removed and separated into seagrass species. Plant material (rhizomes and roots) was sieved out from sediment and separated into species. All plant material was dried at $105^{\circ} \mathrm{C}$ and weighed.

Primary productivity. The diel curve procedure described by Odum \& Hoskin (1958) was used to determine gross community productivity and respiration from changes in axygen concentration in the water flowing over the seagrass bed. Techniques for determining productivity that are based on measurements of changes in oxygen concentration in the water around seagrasses give good estimates of the contribution of algae as well as the seagrasses (see 'Discussion', and Lindeboom \& Sandee 1989).

To determine the relative contributions of benthic and pelagic organisms to the uptake of oxygen from the water column, oxygen changes were measured in enclosed duplicate samples of the water column together with and separate from the benthos. Samples of the water column were enclosed in $4.5 \mathrm{l}$ clear glass 
bottles and incubated in situ. Cores (100 mm diameter) containing sediment, macroalgae and seagrass were collected and clear acrylic chambers (2 l capacity) placed over them. They were incubated underwater in the seagrass bed. The water in each enclosure was stirred before oxygen concentrations were measured.

The photosynthetic rates of the seagrasses were determined with the lacunal gas technique (Roberts \& Moriarty 1987). Measurements were made on shoots of seagrasses with pipettes attached in place of the rhizome. Four shoots were pooled for each sample. The shoots were returned to the seagrass bed and thus were exposed to natural conditions of light, temperature and water movement. Depth was recorded each time the gas volume was measured, and the volume was corrected to that at atmospheric pressure. Calibration of the lacunal gas method for Syringodium isoetifolium and Cymodocea serrulata has been reported elsewhere (Roberts \& Moriarty 1987). For this work, it was assumed that the composition of the gas in the lacunae of the other species was the mean of that in Zostera capricornil, S. isoetifolium and C. serrulata, viz. 33.6\% oxygen (range 32.2 to 34.3 ) (Roberts \& Moriarty 1987). Gross productivity in terms of carbon was calculated from the values for oxygen production, assuming a 1:1 molar ratio (Roberts \& Moriarty 1987). An analysis of variance was used to examine differences between seasons.

Bacterial productivity. Bacterial growth rates were determined from rates of tritiated thymidine incorporation into DNA (Moriarty \& Pollard 1981, 1982, Pollard \& Moriarty 1984).

On each sampling occasion, 4 replicate cores of sediment ( $8 \mathrm{~mm}$ diameter, $4 \mathrm{~cm}$ deep) were collected for incubation with thymidine, 2 cores each were collected for determining blank values and numbers of bacteria. For each sample to be incubated with tritiated thymidine, the upper $2 \mathrm{~mm}$ was extruded and dropped into a plastic tube with $50 \mu$ of filtered seawater; the next $8 \mathrm{~mm}$ was kept for determining dry weight of the sediment. At each $1 \mathrm{~cm}$ depth interval, a further $2 \mathrm{~mm}$ section was sampled. Tritiated thymidine was added $\left(25 \mu \mathrm{Ci}, 2.5 \mathrm{nmol}\right.$ [methy]- ${ }^{3} \mathrm{H}$ ] thymidine) and samples were incubated for $10 \mathrm{~min}$. Ethanol $(80 \% \mathrm{v} / \mathrm{v}$, containing $100 \mathrm{mg} \mathrm{l}^{-1}$ thymidine) was added and samples were transported to the laboratory. The ethanol was removed after centrifuging by aspirating off the fluid. Two $\mathrm{ml}$ of $\mathrm{NaOH}(0.3 \mathrm{M})$, containing $10 \mathrm{mM}$ thymidine, was added. Samples were heated at $100^{\circ} \mathrm{C}$ for $30 \mathrm{~min}$, cooled, centrifuged, washed and then dialysed as described by Pollard (1987).

Water samples $(25 \mathrm{ml}$ each) were incubated with $20 \mu \mathrm{Ci}$ tritiated thymidine (18 nM final concentration) for $10 \mathrm{~min}$ in summer and $20 \mathrm{~min}$ at other seasons. Formaldehyde $(0.5 \% \mathrm{v} / \mathrm{v}$ final concentration $)$ was added to preserve the samples, which were then filtered at the laboratory, and washed with trichloroacetic acid as described by Pollard \& Moriarty (1984).

Bacterial productivity was determined in the fine, flocculent material that settles onto the seagrasses and sediment in calm conditions, but is easily resuspended by disturbance. Covers (100 $\mathrm{mm}$ diameter), with 21 chambers attached, were carefully placed over the seagrass. The flocculent material was then resuspended by stirring and $5 \mathrm{ml}$ samples of the $2 \mathrm{l}$ volume were taken by syringe through ports in the chamber. Incubations with tritiated thymidine $(90 \mathrm{nM})$ were treated as described above for water samples.

Numbers of bacteria were counted in samples of water and sediment that were preserved in formaldehyde $(0.5 \% \mathrm{v} / \mathrm{v})$. Direct microscopic counts and size measurements of bacteria were made using epifluorescence microscopy and acridine orange (Hobbie et al. 1977). The average carbon content of bacteria was $40 \mathrm{fg} \mathrm{cell}^{-1}$, based on the factor of $220{\mathrm{fg} \mu \mathrm{m}^{-3}}^{-3}$ (Bratbak \& Dundas 1984).

The growth rates and productivity of the bacteria were calculated as described by Moriarty (1986). A conversion factor of $5 \times 10^{17}$ cells produced per mol of thymidine incorporated was used (Moriarty 1988). Analyses of variance were used on log-transformed values of radioactivity (disintegrations per minute) in DNA (i.e. bacterial productivity), numbers of bacteria per core and specific growth rates (productivity divided by numbers) to examine differences due to time of day, depth in the sediment and season.

\section{RESULTS}

\section{Primary production}

The shoot density and biomass of the seagrasses was variable within the study sites (Tables 1 and 2). Root and rhizome biomass was greatest in the top $4 \mathrm{~cm}$ of sediment and decreased rapidly with depth at all 3 sites (Tables 1, 2 and 3). An exception was Halodule uninervis at the river mouth after January (Table 2). H. uninervis in the study area was covered by sand during a cyclone in February 1985. Biomass and shoot density were variable, due to a patchy distribution of seagrasses (Table 3). Macroalgae were the dominant components of the above-ground biomass on the reef flat, ranging from 63 to $72 \%$ of the total (Table 3 ).

The photosynthetic rate per unit leaf weight was significantly greater in summer than in winter in Cymodocea rotundata $(\mathrm{p}<0.5)$ and Syringodium isoetifolium ( $\mathrm{p}<0.005$ ) (Fig. 2). Seasonal variation was apparent, with fastest growth in spring, in Thalassia hemprichii $(\mathrm{p}=0.01)$. No significant seasonal variation 
Table 1 Biomass of seagrass at the bay site (see Fig. 1). Means and standard deviations are shown; $\mathrm{n}=6$ (except July, $n=4$ )

\begin{tabular}{|c|c|c|c|c|c|c|c|}
\hline \multirow{2}{*}{$\begin{array}{l}\text { Species/ } \\
\text { Month (1985) }\end{array}$} & \multicolumn{2}{|c|}{ Shoot density } & \multicolumn{2}{|c|}{ Leaf biomass } & \multicolumn{3}{|c|}{ Root biomass } \\
\hline & No. $m^{-2}$ & $\mathrm{SD}$ & $\mathrm{g} \mathrm{m}^{-2}$ & $\mathrm{SD}$ & Depth $(\mathrm{cm})$ & $\mathrm{g} \mathrm{m}^{-2}$ & $\mathrm{SD}$ \\
\hline \multicolumn{8}{|c|}{ Syringodium isoetifolium } \\
\hline January & 6500 & 1300 & 130 & 25 & $\begin{array}{l}0-4 \\
4-8 \\
8-12\end{array}$ & $\begin{array}{r}650 \\
130 \\
25\end{array}$ & $\begin{array}{r}280 \\
130 \\
45\end{array}$ \\
\hline May & 3360 & 2400 & 160 & 110 & $\begin{array}{l}0-4 \\
4-8 \\
8-12\end{array}$ & $\begin{array}{r}345 \\
85 \\
40\end{array}$ & $\begin{array}{r}100 \\
45 \\
20\end{array}$ \\
\hline July & 9300 & 380 & 22 & 7 & $\begin{array}{l}0-4 \\
4-8 \\
8-12\end{array}$ & $\begin{array}{r}170 \\
160 \\
50\end{array}$ & $\begin{array}{r}75 \\
150 \\
40\end{array}$ \\
\hline October & 2900 & 2000 & 270 & 190 & $\begin{array}{l}0-4 \\
4-8\end{array}$ & $\begin{array}{l}380 \\
170\end{array}$ & $\begin{array}{r}100 \\
70\end{array}$ \\
\hline \multicolumn{8}{|c|}{ Cymodocea serrulata } \\
\hline May & 350 & 300 & 50 & 40 & $\begin{array}{l}0-4 \\
4-8\end{array}$ & $\begin{array}{l}70 \\
12\end{array}$ & $\begin{array}{l}25 \\
20\end{array}$ \\
\hline July & 770 & 280 & 120 & 17 & $\begin{array}{l}0-4 \\
4-8\end{array}$ & $\begin{array}{r}115 \\
25\end{array}$ & $\begin{array}{l}80 \\
32\end{array}$ \\
\hline October & 270 & 200 & 80 & 60 & $\begin{array}{l}0-4 \\
4-8\end{array}$ & $\begin{array}{l}50 \\
20\end{array}$ & $\begin{array}{l}30 \\
20\end{array}$ \\
\hline
\end{tabular}

Table 2. Halodule uninervis. Biomass at the river mouth site (Fig. 1). Means and standard deviations are shown

\begin{tabular}{|c|c|c|c|c|c|c|c|c|c|c|}
\hline \multirow{2}{*}{$\begin{array}{l}\text { Month } \\
\text { (1985) }\end{array}$} & \multicolumn{3}{|c|}{ Shoot density } & \multicolumn{3}{|c|}{ Leaf biomass } & \multicolumn{4}{|c|}{ Root biomass } \\
\hline & No. $m^{-2}$ & $\mathrm{SD}$ & $\mathrm{n}$ & $\mathrm{g} \mathrm{m}^{-2}$ & $\mathrm{SD}$ & $\mathrm{n}$ & $\begin{array}{c}\text { Depth } \\
(\mathrm{cm})\end{array}$ & $\mathrm{g} \mathrm{m}^{-2}$ & $\mathrm{SD}$ & $\mathrm{n}$ \\
\hline January & 16000 & 7000 & 5 & 185 & 95 & 5 & $\begin{array}{l}0-4 \\
4-8 \\
8-12\end{array}$ & $\begin{array}{l}590 \\
170 \\
120\end{array}$ & $\begin{array}{r}244 \\
76 \\
110\end{array}$ & $\begin{array}{l}5 \\
5 \\
5\end{array}$ \\
\hline May & 9600 & 5000 & 4 & 60 & 32 & 4 & $\begin{array}{l}0-4 \\
4-8 \\
8-12\end{array}$ & $\begin{array}{r}82 \\
130 \\
160\end{array}$ & $\begin{array}{l}68 \\
35 \\
60\end{array}$ & $\begin{array}{l}4 \\
4 \\
4\end{array}$ \\
\hline July & 13000 & 3000 & 4 & 78 & 15 & 4 & $\begin{array}{l}0-4 \\
4-8 \\
8-12\end{array}$ & $\begin{array}{r}83 \\
63 \\
150\end{array}$ & $\begin{array}{l}36 \\
26 \\
70\end{array}$ & $\begin{array}{l}4 \\
4 \\
4\end{array}$ \\
\hline October & 9200 & 2000 & 5 & 35 & 9 & 5 & $\begin{array}{l}0-4 \\
4-8 \\
8-12\end{array}$ & $\begin{array}{l}163 \\
104 \\
150\end{array}$ & $\begin{array}{l}55 \\
34 \\
75\end{array}$ & $\begin{array}{l}5 \\
5 \\
5\end{array}$ \\
\hline
\end{tabular}

in productivity of Cymodocea serrulata and Halodule uninervis was observed (Fig. 2).

The productivity of the seagrasses per shoot varied significantly between seasons for all species. It was 6 times smaller in autumn and winter than in summer for Syringodium isoetifolium $(\mathrm{p}<0.001)$ and 3 times for Halodule uninervis $(\mathrm{p}<0.01)$; Cymodocea rotundata was twice as productive in summer as in the other seasons $(p<0.05)$ (Tables 4 to 6 ). There were not enough data to determine whether Cymodocea serrulata was more productive in summer, but it was significantly more productive in spring $(p<0.01)$ (Table 4). Thalassia hemprichii was more productive in spring than at other seasons $(p<0.01)$ (Table 5). The 
Table 3. Plant biomass on the reef flat site (Fig. 1). Sediment was about $5 \mathrm{~cm}$ deep, on a hard carbonate substrate. Means and standard deviations are shown $(n=6)$

\begin{tabular}{|c|c|c|c|c|c|c|}
\hline \multirow{2}{*}{$\begin{array}{l}\text { Species/ } \\
\text { Month (1985) }\end{array}$} & \multicolumn{2}{|c|}{ Shoot density } & \multicolumn{2}{|c|}{ Leaf biomass } & \multicolumn{2}{|c|}{ Root biomass } \\
\hline & No. $\mathrm{m}^{-2}$ & $\mathrm{SD}$ & $\mathrm{g} \mathrm{m}^{-2}$ & $\mathrm{SD}$ & $\mathrm{g} \mathrm{m}^{-2}$ & $\mathrm{SD}$ \\
\hline \multicolumn{7}{|c|}{ Cymodocea rotundata } \\
\hline January & 450 & 370 & 52 & 43 & 80 & 75 \\
\hline May & 430 & 480 & 50 & 60 & 120 & 110 \\
\hline July & 78 & 140 & 5 & 10 & nd & nd \\
\hline October & 430 & 280 & 30 & 20 & 160 & 220 \\
\hline \multicolumn{7}{|c|}{ Thalassia hemprichii } \\
\hline January & 700 & 240 & 70 & 25 & 490 & 200 \\
\hline May & 650 & 300 & 65 & 31 & 930 & 610 \\
\hline July & 700 & 100 & 75 & 20 & 630 & 450 \\
\hline October & 350 & 200 & 34 & 22 & 650 & 110 \\
\hline \multicolumn{7}{|l|}{ Algae } \\
\hline January & & & 250 & 240 & & \\
\hline May & & & 190 & 110 & & \\
\hline July & & & 210 & 240 & & \\
\hline October & & & 115 & 90 & & \\
\hline
\end{tabular}

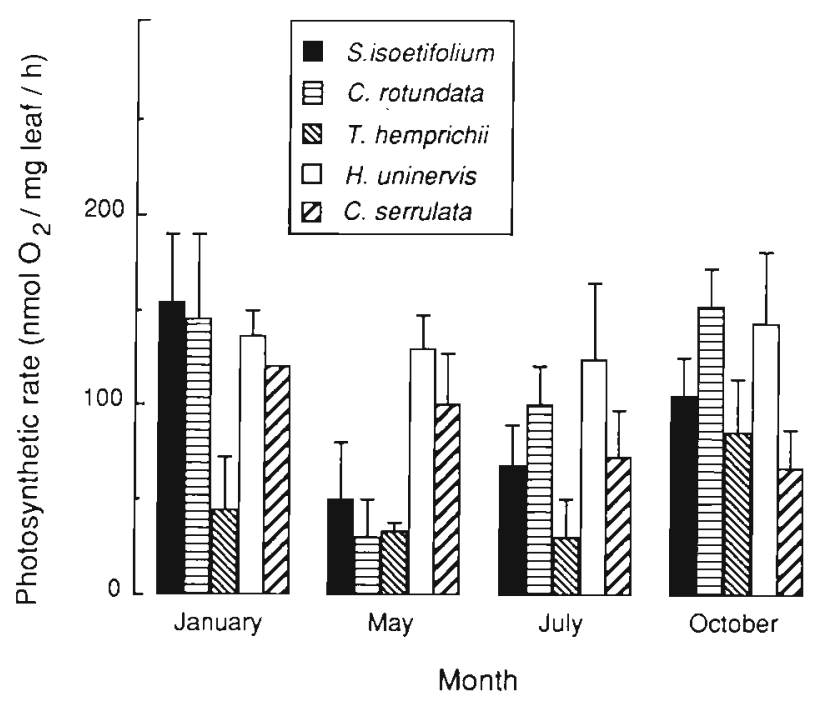

Fig. 2. Photosynthetic rates of seagrasses at the river mouth and reef flat sites, expressed as total oxygen produced per hour, per mg dry weight of leaves. Standard deviations $(n=4)$ are shown

differences in seasonal variation between photosynthetic rate per unit leaf weight and per shoot, especially for $H$. uninervis, occurred because shoots were larger in spring and summer than in winter. C. serrulata was more productive (per shoot) than $S$. isoetifolium in all seasons (Table 4).

The values of shoot productivity were used with the shoot density data to calculate productivity per $\mathrm{m}^{2}$ of the study areas (Tables 4,5 and 6). The highest values for gross productivity on an areal basis $(9.2 \pm 1.7 \mathrm{~g} \mathrm{C}$ $\mathrm{m}^{-2} \mathrm{~d}^{-1}$ ) were for Syringodium isoetifolium in summer
(Table 4). Although the photosynthetic rate of $S$. isoetifolium was lower than Cymodocea serrulata its shoot density was much greater. Similarly, the productivity of Halodule uninervis was high because its shoot density was high, although its photosynthetic rate per shoot was an order of magnitude lower than that of the other seagrasses (Table 6). The site at the river mouth was chosen for having a particularly high density of seagrass compared to the surrounding community, in order to facilitate studies of the effect of seagrass production on bacterial production.

At the bay study site, gross productivity of the community was generally similar to that of the seagrasses (Table 4). In contrast, on the reef flat gross productivity of the community was greater at all seasons than the corresponding productivity of seagrasses; thus the algae were the dominant primary producers (Table 5). This is consistent with the data in Table 3 , showing macroalgal biomass to be more than the leaf biomass of seagrasses. At the river mouth, there was little correspondence between community and seagrass productivities, but as pointed out above the species composition and shoot density at the study site was different from that of the surrounding community (Table 6). Variability due to environmental factors could not be estimated, due to logistical problems that prevented repeating measurements of diel changes in oxygen concentration over a series of days or weeks.

The marked diel variation in oxygen concentration in the water was reproduced when cores of sediment were enclosed in chambers, but not when water alone was enclosed, indicating that benthic organisms were responsible for much of the respiration (Fig. 3). 
Table 4. Primary productivity of seagrasses and the whole communty at the bay site. Values for seagrasses are compared on a per shoot and areal basis. Community productivity $(\mathrm{P})$ and respiration $(\mathrm{R})$ were determined by diurnal changes in oxygen concentration in water, for which the ranges are shown. Values are means \pm standard deviations $(n=4)$

\begin{tabular}{|c|c|c|c|c|c|c|c|c|c|}
\hline \multirow{3}{*}{$\begin{array}{l}\text { Month } \\
(1985)\end{array}$} & \multirow{2}{*}{$\begin{array}{l}\text { Syringodium } \\
\text { isoetifolium }\end{array}$} & \multirow{2}{*}{$\begin{array}{c}\text { Cymodocea } \\
\text { serrulata }\end{array}$} & \multirow[t]{3}{*}{ S. isoetifolium } & \multirow[t]{2}{*}{ C. serrulata } & \multirow{3}{*}{$\begin{array}{c}\text { Total } \\
\text { seagrass } \\
\left.d^{-1}\right)\end{array}$} & \multicolumn{2}{|c|}{ Community } & \multicolumn{2}{|c|}{ Oxygen } \\
\hline & & & & & & $\mathrm{P}$ & $\mathrm{R}$ & $\operatorname{Max}$ & Min. \\
\hline & \multicolumn{2}{|c|}{$\left(\mathrm{mg} C\right.$ shoot $\left.^{-1} \mathrm{~d}^{-1}\right)$} & & $\left(g \subset m g^{-2} d^{-1}\right)$ & & & & (mg & $\left.2^{-3}\right)$ \\
\hline January & $1.4 \pm 0.3$ & $2.0^{\mathrm{a}}$ & $9.2 \pm 1.7$ & $0.15 \pm 0.3$ & 9.3 & 9.3 & 7.6 & 10.2 & 6.7 \\
\hline May & $0.42 \pm 0.25$ & $1.7 \pm 0.4$ & $1.4 \pm 1.7$ & $0.6 \pm 0.5$ & 2.0 & 5.7 & 5.4 & 7.9 & 4.2 \\
\hline July & $0.23 \pm 0.07$ & $1.3 \pm 0.4$ & $2.1 \pm 0.1$ & $1.0 \pm 0.4$ & 3.1 & 3.3 & 3.5 & 8.7 & 5.2 \\
\hline October & $1.2 \pm 0.03$ & $3.0 \pm 0.2$ & $3.5 \pm 3.3$ & $0.8 \pm 0.7$ & 4.3 & 6.0 & 5.1 & 10.5 & 5.4 \\
\hline
\end{tabular}

Table 5. Primary productivity of seagrasses and whole community on the reef flat ( \pm standard deviation, $n=4$ ). See legend to Table 4 for further details

\begin{tabular}{|c|c|c|c|c|c|c|c|c|c|}
\hline \multirow{3}{*}{$\begin{array}{l}\text { Month } \\
\text { (1985) }\end{array}$} & \multirow{2}{*}{$\begin{array}{l}\text { Cymodocea } \\
\text { rotundata }\end{array}$} & \multirow{2}{*}{$\begin{array}{c}\text { Thalassia } \\
\text { hemprichii }\end{array}$} & \multirow[t]{3}{*}{ C. rotundata } & \multirow[t]{2}{*}{ T hemprichii } & \multirow{3}{*}{$\begin{array}{c}\text { Total } \\
\text { seagrass } \\
\left.\mathrm{d}^{-1}\right)\end{array}$} & \multicolumn{2}{|c|}{ Community } & \multicolumn{2}{|c|}{ Oxygen } \\
\hline & & & & & & $P$ & $\mathrm{R}$ & Max & Min \\
\hline & \multicolumn{2}{|c|}{$\left(\mathrm{mgC}\right.$ shoot $\left.{ }^{-1} \mathrm{~d}^{-1}\right)$} & & $\left(g \subset m g=2 d^{-1}\right)$ & & & & \multicolumn{2}{|c|}{$\left(\mathrm{mg} \mathrm{O}_{2} \mathrm{l}^{-1}\right.$} \\
\hline January & $2.2 \pm 0.7$ & $0.6 \pm 0.4$ & $1.0 \pm 0.8$ & $0.4 \pm 0.3$ & 1.4 & 8.4 & 8.0 & 12.4 & 3.9 \\
\hline May & $0.4 \pm 0.3$ & $0.4 \pm 0.1$ & $0.2 \pm 0.2$ & $0.3 \pm 0.1$ & 0.5 & 6.3 & 4.6 & 9.0 & 2.8 \\
\hline July & $0.8 \pm 0.2$ & $0.4 \pm 0.2$ & $0.1 \pm 0.2$ & $0.1 \pm 0.03$ & 0.2 & 3.3 & 2.9 & 9.8 & 5.6 \\
\hline October & $1.3 \pm 0.2$ & $1.1 \pm 0.4$ & $0.6 \pm 0.4$ & $0.4 \pm 0.2$ & 1.0 & 5.2 & 4.4 & 5.3 & 10.6 \\
\hline
\end{tabular}

Table 6. Primary productivity of seagrass Halodule uninervis and whole community at the river mouth. See legend to Table 4 for further details. Values are means \pm standard deviations; $\mathrm{n}=4$

\begin{tabular}{|c|c|c|c|c|c|c|}
\hline \multirow{3}{*}{$\begin{array}{l}\text { Month } \\
\text { (1985) }\end{array}$} & \multicolumn{2}{|c|}{ Seagrass productivity } & \multicolumn{2}{|c|}{ Communtity } & \multicolumn{2}{|c|}{ Oxygen } \\
\hline & & \multirow[b]{2}{*}{$g C \mathrm{~m}^{-2} \mathrm{~d}^{-1}$} & $P$ & $\mathrm{R}$ & Max. & Min. \\
\hline & $\operatorname{mg} C$ shoot ${ }^{-1} d^{-1}$ & & \multicolumn{2}{|c|}{$\left(g \subset m^{-2} d^{-1}\right)$} & \multicolumn{2}{|c|}{$\left(\mathrm{mg} \mathrm{O}_{2} \mathrm{l}^{-1}\right)$} \\
\hline January & $0.22 \pm 0.02$ & $3.5 \pm 0.1$ & 2.7 & 1.2 & 6.1 & 4.7 \\
\hline May & $0.09 \pm 0.01$ & $0.9 \pm 0.06$ & 3.4 & 3.0 & 9.1 & 6.2 \\
\hline July & $0.08 \pm 0.03$ & $1.1 \pm 0.1$ & 3.4 & 2.9 & 10.2 & 3.5 \\
\hline October & $0.11 \pm 0.03$ & $1.0 \pm 0.06$ & 4.0 & 4.0 & 12.9 & 6.2 \\
\hline
\end{tabular}

\section{Bacterial production}

In the water column over the reef flat, specific growth rates of bacteria varied significantly, both diurnally and seasonally $(p<0.01)$. The most rapid growth rates were observed in summer and the slowest in winter (Fig. 4). The diel variation was linked to the tides; growth rates were slower at high tide than at low tide (Fig. 4). Both growth rates and productivity of bacteria were significantly greater over the seagrass bed than further offshore at both the reef flat $(\mathrm{p}<0.01)$ and bay sites $(\mathrm{p}<$ 0.001 ) (Fig. 5). Bacterial numbers were nearly constant across the transect (range: $\pm 5 \%$ of the mean), so specific growth rates varied in a similar manner to productivity (Fig. 5). The average daily productivity and specific growth rates of bacteria in the water col- umn were greater in summer than at other seasons, but the absolute areal values are small compared to sediment values (Tables 7 and 8). Productivity was lowest in winter.

Growth rates of bacteria attached to the flocculent material were similar to those free in the water column, but with 2 exceptions, productivities were greater (Table 7). Like those in the water column, these values were very low compared to sediment on an areal basis. Productivity of bacteria in the flocculent material on the Syringodium isoetifolium was very variable, reflecting variability in the amount of flocculent material on the seagrass (Table 7 ).

Most of the bacterial biomass in both seagrass beds was produced in the sediment with greatest productivity in summer (Tables 7 and 8 ; Fig. 6). Spatial variabil- 


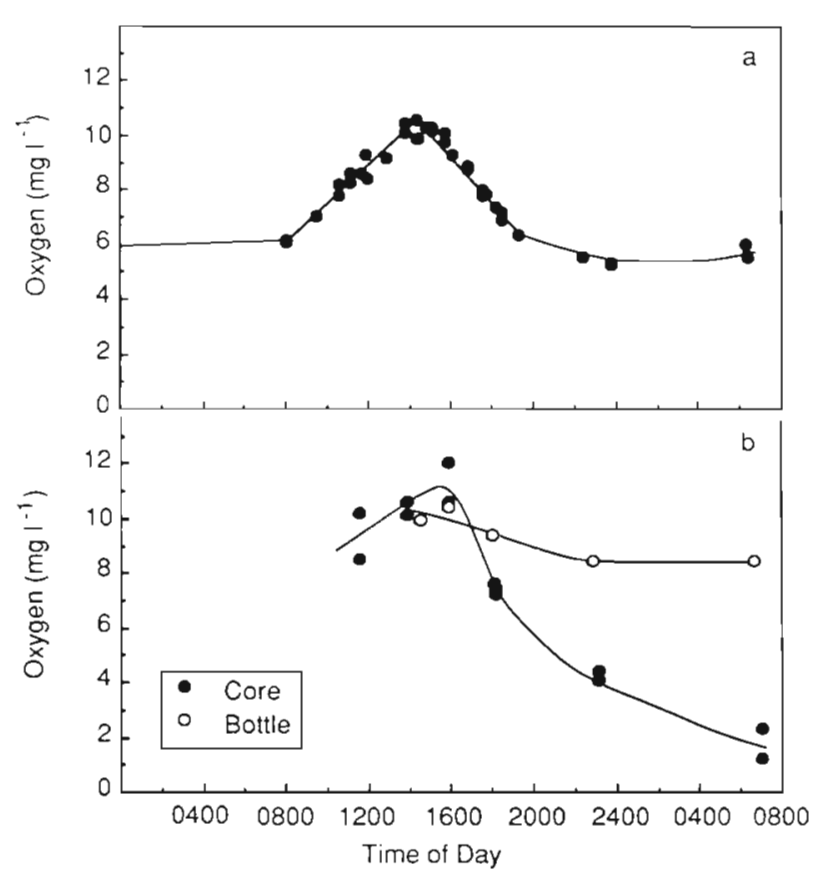

Fig. 3. Example of diel changes during October in oxygen concentration in the water. (a) Water over the reef flat; (b) in chambers containing cores of sediment with algae and seagrass and in bottles with water only; where separate points are not shown at each time interval, values for duplicates were within the size of the plot symbols

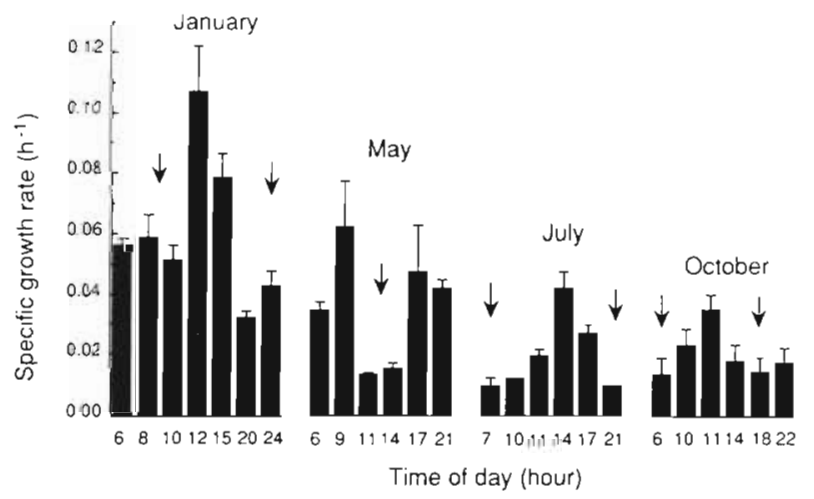

Fig. 4. Specific growth rates of bacteria in the water column over the reef flat at different seasons and times of the day.

Times of high tide are indicated by arrows

ity was large ( $\pm 20 \%$ of mean) and tended to obscure patterns in diel variation. A 3-way analysis of variance of productivity at different times of the day with season and depth in the sediment showed that there was no significant interaction between time of day and the other factors, and that there was a significant difference between the early morning values and other times of the day $(p=0.0001$; Student-Newman-Keuls test at $p=0.05$ ). The early morning values were, therefore, deleted from further analyses to show seasonal and depth effects. Specific growth rates were calculated
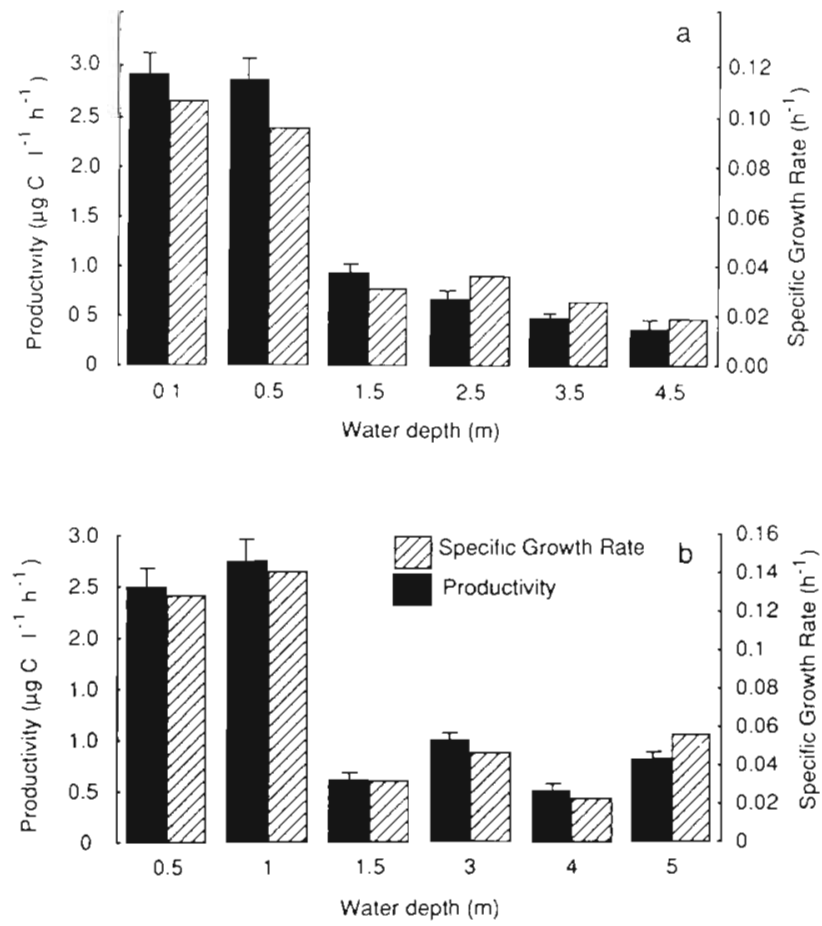

Fig. 5. Productivity and specific growth rates of bacteria in the water column on a rising tide at mid-tide height in transects from nearshore to $1 \mathrm{~km}$ offshore in autumn; water temperature $29^{\circ} \mathrm{C}$. Water depths at low tide are indicated. Duplicate determinations were made of both numbers and productivity; the range of variation is indicated for productivity. (a) Bay. Seagrass shoot density decreased with increasing water depth to $2.5 \mathrm{~m}$. No seagrass was present below $3.5 \mathrm{~m}$. (b) Reef flat. The reef crest was at $2 \mathrm{~m}$ depth. No seagrasses or macroalgae were present inside the reef crest at $1.5 \mathrm{~m}$

only from midday values in order to minimise effects of diel variation.

Bacterial productivities were particularly high at the surface of the sediment in summer at the river mouth and on the reef flat, and decreased towards the bottom of the sediment profile (Fig. 6). An analysis of variance showed that these differences were very significant and that there was a significant depth interaction with season (Table 9). In spring, productivity was high at 3 to $4 \mathrm{~cm}$ in the sediment profile; in winter, productivities were low throughout the sediment (Fig. 6). At the bay site, i.e. around Syringodium isoetifolium, most of the variation was due to seasonal rather than depth differences (shown by the different $F$ values in Table 9). Bacterial productivity in the sediment on the reef flat was 5 to 45 times greater than that in the water and flocculent material (Table 7). Total values for integrated daily productivity were greater in spring and summer than in autumn and winter (Tables 7 and 8 ).

The specific growth rates of bacteria varied with season, being most rapid in summer at the sediment surface in all 3 seagrass beds (Fig. 7). An analysis of 
Table 7. Bacterial productivity $(\mathrm{P})$ and specific growth rates $(\mu)$ at the bay and reef flat sites. Specific growth rates are average values for the day; the productivity values were integrated over a day; sediment values were integrated down to $12 \mathrm{~cm}$ depth in the bay and $7 \mathrm{~cm}$ on the reef flat. Standard errors of bacterial numbers were between 5 and $10 \%$ of the mean. Total bacterial productivity is shown as a rounded percentage of total community gross productivity

\begin{tabular}{|c|c|c|c|c|c|c|c|c|}
\hline \multirow{2}{*}{$\begin{array}{l}\text { Month } \\
\text { (1985) }\end{array}$} & \multicolumn{3}{|c|}{ Seawater } & \multicolumn{2}{|c|}{ Flocculent material } & \multirow{2}{*}{$\begin{array}{c}\text { Sediment } \\
\text { P } \\
\left(\mathrm{g} C \mathrm{~m}^{2} \mathrm{~d}^{-1}\right)\end{array}$} & \multicolumn{2}{|l|}{ Total } \\
\hline & $\begin{array}{c}\text { No. } \\
\left(10^{9} l^{-1}\right)\end{array}$ & $\left(h^{-1}\right)$ & $\left(\mathrm{mgC} \mathrm{m} \mathrm{m}^{-2} \mathrm{~d}^{-1}\right)$ & $\left(h^{\mu l}\right)$ & $\left(\mathrm{mg} \mathrm{C} \mathrm{m}^{-2} \mathrm{~d}^{-1}\right)$ & & $\frac{P}{\left(g C m^{-2} d^{-1}\right)}$ & $\begin{array}{c}\% \\
\mathrm{PP}\end{array}$ \\
\hline \multicolumn{9}{|l|}{ Bay: } \\
\hline January & 1.3 & 0.08 & 100 & 0.05 & 110 & 4.6 & 4.8 & 50 \\
\hline May & 1.8 & 0.06 & 90 & 0.03 & 10 & 0.9 & 1.0 & 20 \\
\hline July & 1.2 & 0.05 & 40 & 0.08 & 290 & 1.7 & 2.0 & 60 \\
\hline October & 1.4 & 0.07 & 80 & 0.08 & 100 & 2.0 & 2.2 & 40 \\
\hline \multicolumn{9}{|l|}{ Reef flat: } \\
\hline January & 7.5 & 0.12 & 48 & 0.05 & 31 & 3.6 & 3.7 & 45 \\
\hline May & 8.5 & 0.07 & 32 & & 70 & 0.5 & 0.6 & 10 \\
\hline July & 5.0 & 0.04 & 11 & 0.02 & 72 & 0.7 & 0.8 & 30 \\
\hline October & 7.3 & 0.04 & 17 & 0.12 & 144 & 3.5 & 3.6 & 70 \\
\hline
\end{tabular}

Table 8. Bacterial productivity $(\mathrm{P})$ and specitic growth rates $(\mu)$ at the river mouth (Halodule uninervis community). Specific growth rates are average values for the day; the productivity values were integrated over a day; sediment values were integrated down to $12 \mathrm{~cm}$ depth. Standard errors of bacterial numbers were between 5 and $10 \%$ of the mean. Total bacterial productivity is shown as a percentage of total community gross productivity (\% PP)

\begin{tabular}{|c|c|c|c|c|c|c|}
\hline \multirow{2}{*}{$\begin{array}{l}\text { Month } \\
(1985)\end{array}$} & \multicolumn{3}{|c|}{ Seawater } & \multirow{2}{*}{$\begin{array}{c}\text { Sediment } \\
\mathrm{P} \\
\left(\mathrm{g} \mathrm{C} \mathrm{m}^{-2} \mathrm{~d}^{-1}\right)\end{array}$} & \multicolumn{2}{|l|}{ Total } \\
\hline & $\begin{array}{c}\text { No. } \\
\left(10^{9} l^{-1}\right)\end{array}$ & $\stackrel{\mu}{u}\left(\mathrm{~h}^{-1}\right)$ & $\left(\mathrm{mgC} \mathrm{m}^{-2} \mathrm{~d}^{-1}\right)$ & & $\frac{\mathrm{P}}{\left(\mathrm{gC} \mathrm{m}^{-2} \mathrm{~d}^{-1}\right)}$ & $\begin{array}{l}\% \\
\mathrm{PP}\end{array}$ \\
\hline January & 1.1 & 0.1 & 90 & 2.4 & 2.5 & 90 \\
\hline May & 1.0 & 0.04 & 30 & 0.8 & 0.9 & 25 \\
\hline July & 0.7 & 0.03 & 10 & 0.6 & 0.6 & 20 \\
\hline October & 1.2 & 0.05 & 30 & 1.2 & 1.2 & 30 \\
\hline
\end{tabular}

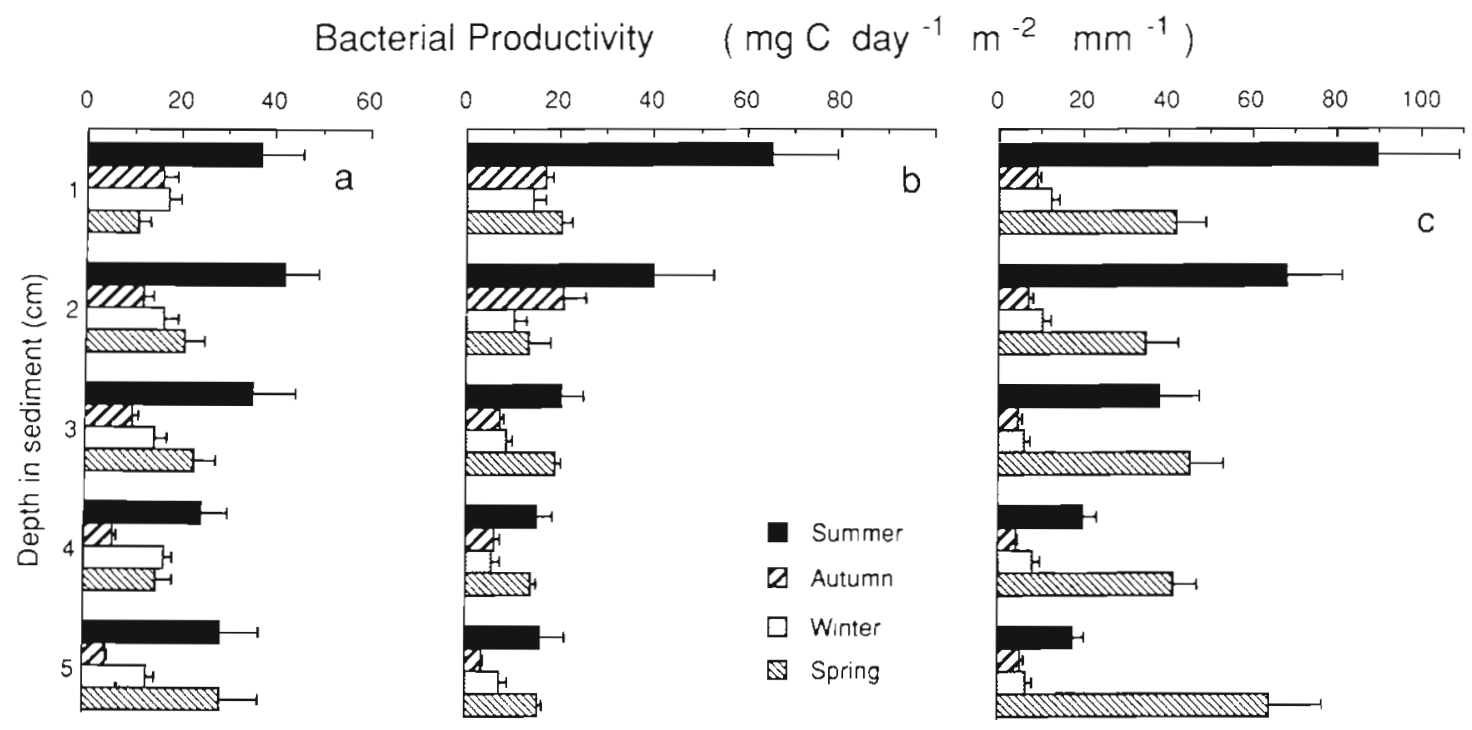

Fig. 6. Depth profiles of bacterial productivity in sediment. (a) Bay; (b) river mouth; and (c) reef flat. See Table 9 tor analyses of variance 
Table 9. Analyses of variance in bacterial productivity, numbers and specific growth rates in sediment due to season and depth in the sediment at the 3 sites. $n$ : Number of samples for each site; $d f$ : degrees of freedom

\begin{tabular}{|c|c|c|c|c|c|c|c|c|c|c|c|}
\hline \multirow[t]{2}{*}{ Site } & \multirow[t]{2}{*}{ Source } & \multirow[t]{2}{*}{$d f$} & \multicolumn{3}{|c|}{ Bacteral productivity } & \multicolumn{3}{|c|}{ Numbers of bacteria } & \multicolumn{3}{|c|}{ Specific growth rates } \\
\hline & & & $\mathrm{n}$ & F & $\mathrm{P}$ & $\mathrm{n}$ & F & $\mathrm{P}$ & $\mathrm{n}$ & $\mathrm{F}$ & $P$ \\
\hline Bay & $\begin{array}{l}\text { Depth } \\
\text { Season } \\
\text { Depth } \times \text { Season }\end{array}$ & $\begin{array}{r}4 \\
3 \\
12\end{array}$ & 280 & $\begin{array}{r}2.8 \\
46.1 \\
2.5\end{array}$ & $\begin{array}{l}0.026 \\
0.0001 \\
0.004\end{array}$ & 65 & $\begin{array}{r}3.7 \\
26.5 \\
13.3\end{array}$ & $\begin{array}{l}0.01 \\
0.0001 \\
0.0001\end{array}$ & 59 & $\begin{array}{l}1.7 \\
3.1 \\
3.97\end{array}$ & $\begin{array}{l}0.16 \\
0.036 \\
0.0005\end{array}$ \\
\hline River mouth & $\begin{array}{l}\text { Depth } \\
\text { Season } \\
\text { Depth } \times \text { Season }\end{array}$ & $\begin{array}{r}4 \\
3 \\
12\end{array}$ & 370 & $\begin{array}{r}27.8 \\
44.2 \\
2.6\end{array}$ & $\begin{array}{l}0.0001 \\
0.0001 \\
0.002\end{array}$ & 65 & $\begin{array}{r}3.5 \\
11.9 \\
5.0\end{array}$ & $\begin{array}{l}0.01 \\
0.0001 \\
0.002\end{array}$ & 61 & $\begin{array}{r}1.3 \\
11.3 \\
1.8\end{array}$ & $\begin{array}{l}0.27 \\
0.0001 \\
0.08\end{array}$ \\
\hline Reef flat & $\begin{array}{l}\text { Depth } \\
\text { Season } \\
\text { Depth } \times \text { Season }\end{array}$ & $\begin{array}{r}4 \\
3 \\
12\end{array}$ & 360 & $\begin{array}{c}12.1 \\
145 \\
4.4\end{array}$ & $\begin{array}{l}0.0001 \\
0.0001 \\
0.0001\end{array}$ & 65 & $\begin{array}{c}1.5 \\
189 \\
30.0\end{array}$ & $\begin{array}{l}0.21 \\
0.0001 \\
0.0001\end{array}$ & 58 & $\begin{array}{c}0.96 \\
23.6 \\
2.8\end{array}$ & $\begin{array}{l}0.44 \\
0.0001 \\
0.007\end{array}$ \\
\hline
\end{tabular}

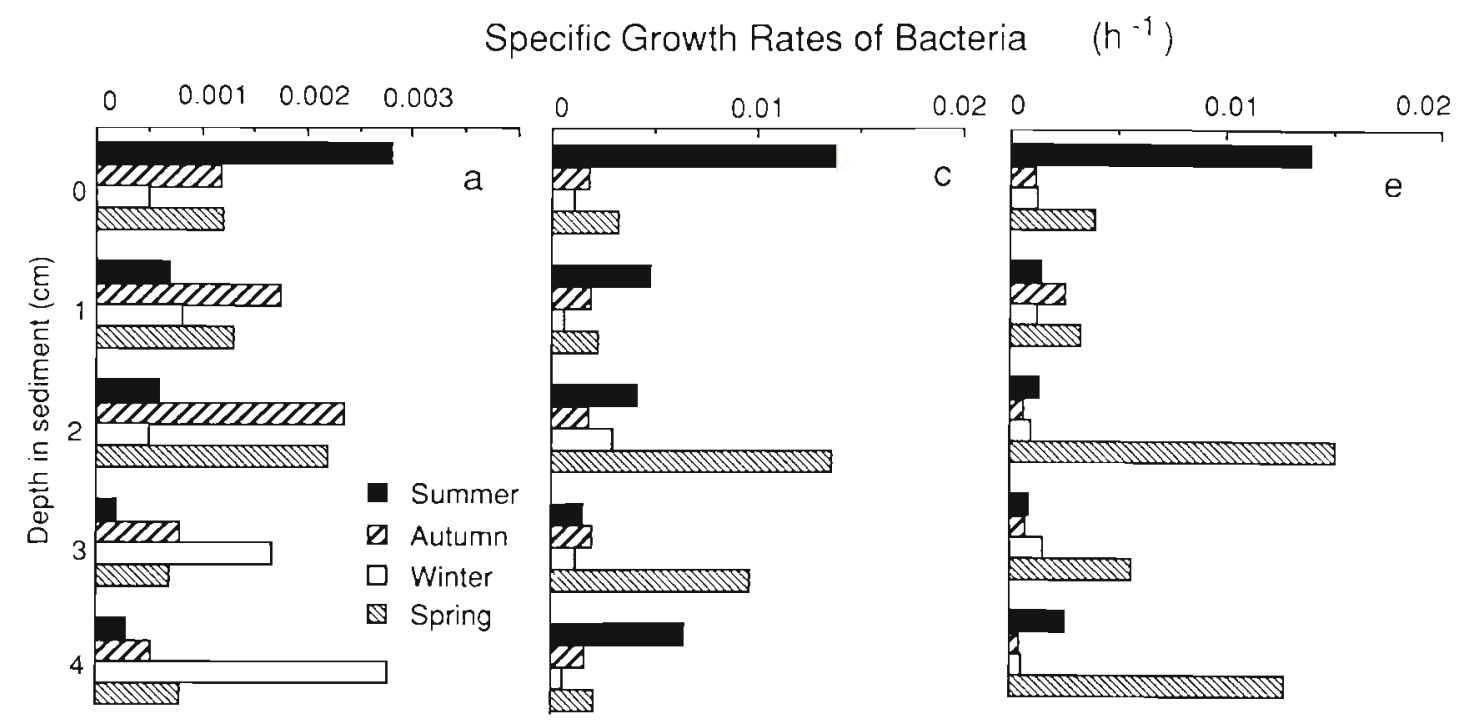

Bacterial Numbers ( $10^{9}$ cells / g dry weight)
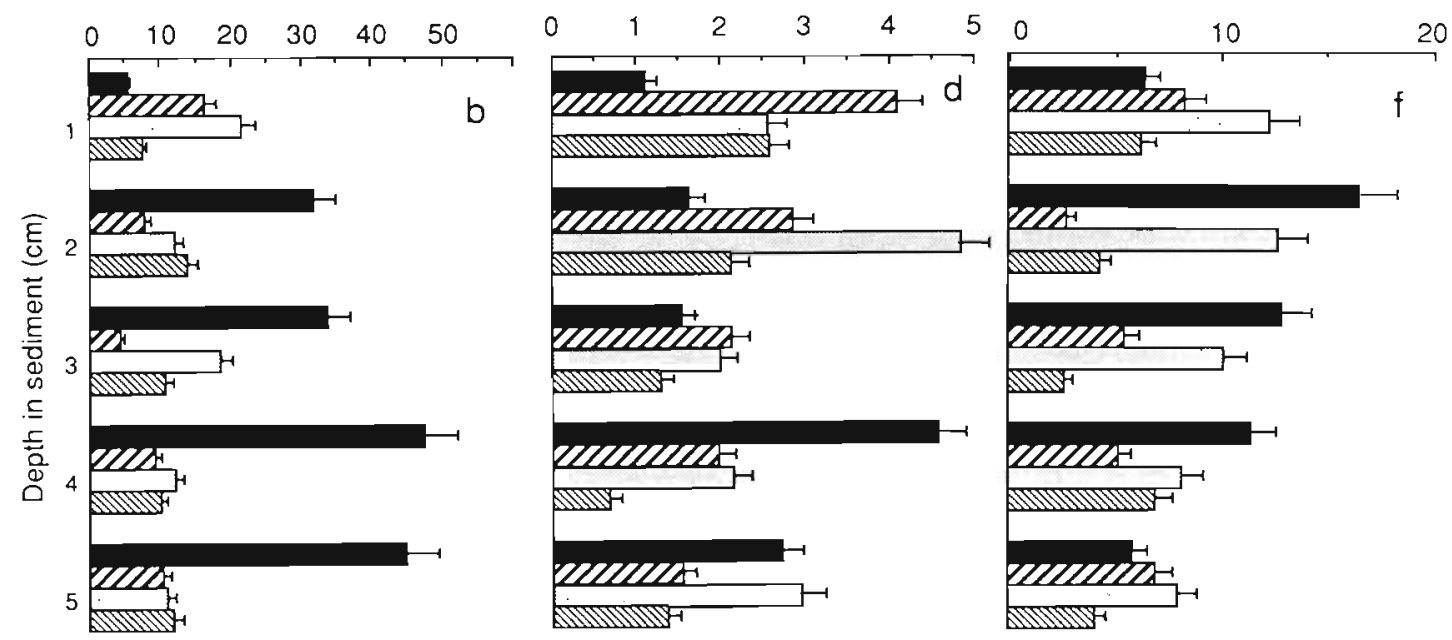

Fig. 7. Specific growth rates of bacteria and numbers of bacteria in the upper $4 \mathrm{~cm}$ of sediment ( $a, b)$ Bay; (c, d) river mouth; and (e, f) reef flat. See Table 9 for analyses of variance 
variance showed that there was a significant interaction between depth and season at the bay and reef flat sites (Table 9). This was due to rapid growth of bacteria below $2 \mathrm{~cm}$ depth during seasons other than summer (Fig. $7 \mathrm{a}, \mathrm{e}$ ). At the river mouth, there was not a significant effect due to depth (Table 9), although the data in Fig. $7 \mathrm{C}$ suggest that there should be because growth rates were rapid in spring at 2 to $4 \mathrm{~cm}$. Bacterial productivities were found to be high in only one of the replicate cores collected at midday; in other words, the effect was caused by spatial variability and was not significant.

Bacterial numbers were about 1 order of magnitude lower in the Halodule uninervis bed (Fig. 7d) than in the Syringodium isoetifolium bed (Fig. $7 \mathrm{~b}$ ), but productivities were similar; thus specific growth rates of bacteria were 5 to 10 times faster in the former (Fig. $7 \mathrm{a}, \mathrm{c}$ ) Although the growth rate of bacteria was faster at the sediment surface than at other depths in January at all sites, the number of bacteria at the surface was Iower (Fig. 7). The number of bacteria at deeper depths was generally greater in summer at the muddy sites (the bay and reef flat). Much of the variance in numbers was due to season, although there was a very significant interaction with depth (Table 9).

\section{DISCUSSION}

\section{Primary productivity}

Temperature was probably an important factor causing the seasonal variation in photosynthetic rates of the seagrasses. The photosynthetic rate per unit leaf weight was lower in some species in winter when the mean temperature was $10^{\circ} \mathrm{C}$ lower. Although light intensity was lower in winter than in summer at the top of the leaf canopy, on sunny days it was above $1000 \mu \mathrm{E}$ $\mathrm{m}^{-2} \mathrm{~s}^{-1}$, which is saturating for at least some of these species (Roberts \& Moriarty 1987). In other species of seagrass, temperature probably has a controlling influence on growth, provided light intensity is high (Kirkman et al. 1982, Bulthuis 1983, Barber \& Behrens 1985. Brouns \& Heijs 1986).

The photosynthetic rate per unit leaf weight of Halodule uninervis did not vary markedly with season, but its daily productivity (per shoot or unit area) was lower in winter, due to the smaller size of the shoots, and the shorter days. The values for gross productivity of Thalassia hemprichii are low for January, possibly because the water was too hot. The measurements were made during a period when low tide occurred around noon, and water temperature on the reef flat reached $38^{\circ} \mathrm{C}$. I. R. Poiner and C. Thorogood (pers. comm.) noted that growth rates of $T$. hemprichii, deter- mined by the plastochrone method at the same site, were depressed at water temperatures of about $40^{\circ} \mathrm{C}$.

Seagrass productivity on an areal basis was considerably greater in summer than in winter for all seagrass beds. The seasonal differences were influenced by various factors, especially photosynthetic rate and shoot density. For example in the bay study area, Syringodium isoetifolium accounted for $98 \%$ of the production in summer and $68 \%$ in the winter because its shoot density was an order of magnitude greater than that of Cymodocea serrulata. Day length was 10 to $15 \%$ shorter in July, so this contributed to lower daily productivity values in winter. Brouns (1987c) found that the production of $S$. isoetifolium, Cymodocea rotundata, $C$. serrulata and Halodule uninervis was greatest in February and March in Papua New Guinea. Where shoot densities were similar, his values for production were not very different from those that we recorded. For example, the shoot density of $S$. isoetifolium at Brouns' Stn 6 was about $7000 \mathrm{~m}^{-2}$ and the productivity was about $9.2 \mathrm{~g}$ ash free dry wt $\mathrm{m}^{-2} \mathrm{~d}^{-1}$, i.e. about $3.7 \mathrm{~g} \mathrm{C} \mathrm{m}^{-2} \mathrm{~d}^{-1}$ in August (Brouns $1987 \mathrm{C}$ ). Our values for July (the nearest corresponding period) were 9000 shoots $\mathrm{m}^{-2}$ and $3.5 \mathrm{~g} \mathrm{C} \mathrm{m}^{-2} \mathrm{day}^{-1}$ (Tables 1 and 4 ).

The values we obtained for gross productivity of a community of Halodule uninervis agreed with those of Lindeboom \& Sandee (1989). Their values ranged from 3.3 to $4.7 \mathrm{~g} \mathrm{C} \mathrm{m}^{-2} \mathrm{~d}^{-1}$ for the whole community in October in Indonesia and ours were $4 \mathrm{~g} \mathrm{C} \mathrm{m}^{-2} \mathrm{~d}^{-1}$, of which the seagrass contributed $25 \%$. They estimated epiphyte production to be about $36 \%$ of the total primary production. Benthic microalgae must also be important contributers to primary production at this site. We found, as they did, that the net production of the community was generally low, i.e. the difference between community respiration and production was low (see Tables 4, 5 and 6). This indicates that much of the primary production was utilised within the community. Where substantial net production was apparent, e.g. at the river mouth and bay sites in January (see Tables 4 and 6), we may conclude that export and/ or deposition of organic matter occurred

\section{Methodology}

The results of the 2 methods used here to determine primary productivity were similar The seagrasses, especially Syringodium isoetifolium, were the dominant plants at the bay site and thus were the major primary producers. Epiphytes were not abundant on $S$. isoetifolium and its dense cover would have shaded benthic microalgae. Thus agreement in values obtained by the 2 different methods could be expected 
at the bay site, in contrast to the values for productivity on the reef flat, where macroalgae were abundant.

The diel curve method for estimating the whole community productivity has limitations, as discussed by Odum \& Hoskin (1958). The factors that substantially affect the accuracy of the results are respiration during the day, diffusion of oxygen to or from the atmosphere. and variation in water depth across the seagrass bed, relative to the measurement station. Diffusion is difficult to measure accurately, yet the values for gross community productivity in the Syringodium bed in January and October (where algae were insignificant) agreed well with the values for seagrasses themselves determined by the lacunal gas method (Table 4). Most oxygen exchange in the water column over a seagrass bed is due to the benthic community (Odum \& Hoskin 1958, Lindeboom \& Sandee 1989).

The diel curve method in the open water column provides an estimate of gross primary productivity and respiration of the whole community. More detailed studies are needed to determine the individual contributions of the major components: seagrasses, macroalgae, epiphytic and epibenthic microalgae. The ratio of net photosynthesis to respiration in seagrasses and green algae is about 5 to 6 , so their contribution to the respiratory losses was not a substantial proportion (Buesa 1977). In other words, net productivity in the macrophytes is about $20 \%$ smaller than gross productivity.

Methods for determining productivity based on oxygen measurements have been criticised (Zieman \& Wetzel 1980). This criticism had been advanced partly because it was not known then how much oxygen passed to the roots via the lacunae, nor whether it was stored. Only about $15 \%$ of oxygen produced during photosynthesis is transported via lacunae to the sediment and would not be accounted for over short-term measurements (Roberts \& Moriarty 1987). In other words, only a little oxygen is stored and thus this is not a serious problem with the method. Lindeboom \& Sandee (1989) have discussed methods for determining productivity that depend on oxygen measurements. and conclude that they are satisfactory. As they point out, no better, simple methods for determining productivity of a whole community are available.

\section{Bacterial productivity}

Bacterial production is dependent on seagrass production on at least 2 time scales. Firstly, bacterial growth rates change over a period of hours in response to exudation of organic matter during photosynthesis (Moriarty \& Pollard 1982, Moriarty et al. 1985). Secondly, over a period of weeks or months, bacteria grow while decomposing dead plant material (Harrison \&
Mann 1975). It seems from our data that bacterial production is coupled to primary production on a seasonal basis, with most activity in summer and least in winter or autumn, even though this is a tropical location, with the lowest temperature that we recorded being $21^{\circ} \mathrm{C}$. The noticeable seasonal variation in bacterial productivity was more pronounced than that in primary productivity, which suggests that the seasonal change of $10^{\circ} \mathrm{C}$ in mean temperature had more impact on bacterial activity than on the plants. Alongi (1988) found that bacterial productivity was lower in mangrove sediment in winter. Furthermore, he found that when intertidal mud banks below mangroves were exposed to air that was cooler than the water, bacterial growth rates decreased (Alongi 1988). Temperature is a very important factor controlling the productivity of bacteria, through its effect on the rate of hydrolysis of organic polymers, especially cellulose and protein. This first step in the decomposition of particulate organic matter, derived from dead leaves, rhizomes and roots of seagrasses, seems to be the rate-limiting one, but few studies have been made of this process (Godshalk \& Wetzel 1977).

On the reef flat and in the bay, both seagrass and bacterial productivity were 5 times lower in winter (July or May) than in summer (Tables 4 and 7). Similarly, at the river mouth seagrass and bacterial productivity were 3 to 4 times lower in winter than in summer (Tables 6 and 8 ). This suggests that the bacterial productivity was limited by the rate of organic matter supply from the seagrasses and that temperature had a controlling influence on metabolic rates. In spring, specific growth rates of bacteria were faster at depths of 2 to $4 \mathrm{~cm}$, which is the main root zone of the seagrasses Syringodium isoetifolium, Thalassia hemprichii and Cymodocea rotundata. This is likely to be due to stimulation of bacterial growth by organic matter exuded from the roots of the seagrasses (see Fig. $7 a, c, e$ ).

The proportion of primary productivity that is utilised by bacteria is variable and not easily determined. It depends on the average growth efficiency for the whole bacterial community and the proportion of biomass to extracellular products formed by the bacteria. The total amount of organic carbon from primary producers needed to support the observed rates of production by the heterotrophic bacteria would be equal to the bacterial productivity if the bacteria were $50 \%$ efficient, and steady state conditions applied, i.e. if rates of respiration and input of organic matter were the same (Strayer 1988, Moriarty 1989). Bacteria in the sediment use not only organic matter supplied directly from the primary producers, but also that recycled from animals and previous bacterial activities. Values for bacterial productivity that are equal to or greater than primary productivity are possible when carbon cycling is tightly 
coupled, and bacterial growth efficiencies are high (see Tables 7 and 8). More frequent sampling would be required to determine how close coupling was temporally.

If the bacteria were $50 \%$ efficient in their use of organic matter, the values reported here indicate that they utilised from 20 to $60 \%$ of primary production at the bay site and 10 to $70 \%$ on the reef flat (Table 7 ). At the river mouth, the corresponding values for the whole community was $90 \%$ in January, but it is not valid to compare bacterial growth in this study site with the whole community. The seagrass productivity at this site was greater than that of the whole community because the shoot density was much higher than nearby. Bacterial productivity was $70 \%$ of seagrass productivity. If most of the organic matter entering the sediment is decomposed by bacteria, the growth efficiency of the bacteria can be estimated (Moriarty 1989). The calculated efficiencies are between 20 and $40 \%$ for the bay site, which are within the ranges quoted for natural systems (Robinson et al. 1982, Findlay et al. 1986). Thus it seems likely that the main fate of primary production in these seagrass beds is recycling to carbon dioxide by bacteria in the sediment (Moriarty 1989).

The higher specific growth rates of bacteria on the sediment surface in summer, as well as the high productivity, indicate that leaf and algal decomposition was more rapid in summer (Figs. 6 and $7 a, c, e$ ). On the reef flat, seagrass root and rhizome biomass was high compared to leaf and algal biomass, which suggests that its decomposition after death would support more bacterial growth than above-ground biomass (Table 3 ). Most bacteria were probably utilising decaying seagrass tissue rather than exudates of organic matter from living seagrasses. Diel trends were sometimes apparent, but were not as marked as those reported elsewhere because they were masked by spatial variability (Moriarty \& Pollard 1982, Moriarty et al. 1986) The sampling strategy was designed to show trends on a broad areal and seasonal basis, rather than individual diel variation.

More information is needed on the rate of root turnover compared to leaf turnover and more frequent measurements of bacterial and primary production are needed to establish how closely production of organic matter is coupled in time to decomposition. There is substantial spatial, seasonal and interannual variation in seagrass biomass in these seagrass beds (I. R. Poiner pers. comm.).

\section{Trophic implications}

A factor contributing to control of bacterial productivity is the effect of grazing on them by animals. We would expect the bacterial population density (num- bers) to be highest at the sediment surface when productivity and specific growth rates were rapid. In January, however, although specific growth rates were rapid, bacterial numbers were lower at the surface than deeper in the sediment at all 3 sites, which is a good indication that grazing by animals was intense (Fig. 7). The sediments were anoxic below about $2 \mathrm{~mm}$ and thus most meiofauna and protozoans would be concentrated in the surface layer (Coull \& Bell 1979). Protozoans are probably the most important grazers on bacteria in sediment, but more information is needed on their interactions with bacteria (Fenchel \& Jørgensen 1977).

The bacterial biomass production each day in summer $\left(4.8 \mathrm{~g} \mathrm{C} \mathrm{m}^{-2} \mathrm{~d}^{-1}\right.$ at the bay site, $3.7 \mathrm{~g} \mathrm{C} \mathrm{m}^{-2} \mathrm{~d}^{-1}$ on the reef flat, and $2.5 \mathrm{~g} \mathrm{C} \mathrm{m}^{-2} \mathrm{~d}^{-1}$ at the river mouth), is a substantial food resource for animals. Even though this is a tropical environment, this resource was much less in winter. It seems, however, that only the bacteria in the surface sediment were grazed to a noticeable extent, and then only in summer.

The grazing activity would decrease the proportion of organic matter that is recycled in the sediment, making it difficult to assess the proportion of seagrass production that is decomposed by bacteria each day. At this stage we cannot determine what proportion of bacterial production is grazed by animals and what is recycled via cell lysis and exudation of organic compounds in the sediment. The lower specific growth rates in the deeper sediment layers, especially in the bay and reef flat sites, suggest that the main fate of organic carbon was recycling within the bacterial community.

Acknowledgement. This work was supported by a Marine Sciences and Technologies grant (No. 81/0319).

\section{LITERATURE CITED}

Alongi, D. M. (1988). Bacterial productivity and microbial biomass in tropical mangrove sediments. Microb. Ecol. 15: $59-79$

Barber, B. J., Behrens, P. J. (1985). Effects of elevated temperature on seasonal in situ productivity of Thalassia testudinum Banks ex Konig and Syringodium filiforme Kutzing. Aquat. Bot. 22: 61-69

Bratbak, G., Dundas, J. (1984). Bacterial. dry matter content and biomass estimations. Appl. environ Microbiol. 48: $755-757$

Brouns, J. J. W. M. (1985). A comparison of the annual production and biomass in three monospecific stands of the seagrass Thalassia hemprichii (Ehrenb.) Aschers. Aquat. Bot. 23: 149-175

Brouns, J. J.W. M. (1987a). Growth patterns in some IndoWest Pacific seagrasses. Aquat. Bot. 28: 39-61

Brouns, J. J. W. M. (1987b). Quantitative and dynamic aspects of a mixed seagrass meadow in Papua New Guinea. Aquat. Bot. 29: 33-47

Brouns, J. J. W. M. $(1987 \mathrm{c})$. Aspects of production and bio- 
mass of four seagrass species (Cymodoceoideae) from Papua New Guinea. Aquat. Bot. 27: 333-362

Brouns, J. J. W. M., Heijs, F. M. L. (1986). Production and biomass of the seagrass Enhalus acoroides (L. f.) Royle and its epiphytes. Aquat. Bot. 25: 21-45

Buesa, R. J. (1977). Photosynthesis and respiration in some tropical marine plants. Aquat. Bot. 3: 203-216

Bulthuis, D. A. (1983). Effects of temperature on the photosynthesis-irradiance curve of the Australian seagrass Heterozostera tasmanica. Mar. Biol. Lett. 4: 47 -57

Coull, B. C., Bell, S. S. (1979). Perspectives of marine meiofaunal ecology. In: Livingston, R. J. (ed.) Ecological processes in coastal and marine systems. Plenum Publishing Corporation, New York, p. 189-216

Fenchel, T. M., Jargensen, B. B. (1977). Detritus food chains of aquatic ecosystems: the role of bacteria. Adv. microb. Ecol. 1: $1-58$

Findlay, S., Carlough, L., Crocker, M. T., Gill, H. K., Meyer, J. L., Smith, P. J. (1986). Bacterial growth on macrophyte leachate and fate of bacterial production. Limnol. Oceanogr. 31 (6): 1335-1341

Godshalk, G. L., Wetzel, R. G. (1977). Decomposition of macrophytes and the metabolism of organic matter in sediments. In: Golterman, H. R. (ed.) Interactions between sediment and fresh water. Dr. W. Junk B.V Publishers, The Hague, p. 258-264

Harrison, P. G., Mann, K. H. (1975). Detritus formation from eelgrass (Zostera marina L.): the relative effects of fragmentation, leaching, and decay. Limnol. Oceanogr 20: 924-934

Hobbie, J. E., Daley, R. J., Jasper, S. (1977). Use of Nuclepore filters for counting bacteria by fluorescence microscopy. Appl. environ. Microbiol. 33: 1225-1228

Kirkman, H., Cook, I. H., Reid, D. D. (1982). Biomass and growth of Zostera capricorni Aschers. in Port Hacking, N. S. W. Australia. Aquat. Bot. 12:57-67

Klug, M. J. (1980). Detritus-decomposition relationships. In: Phillips, R. C. McRoy, C. P. (eds.) Handbook of seagrass biology: an ecosystem perspective. Garland STPM Press, New York, p. 223-245

Lindeboom, H. J., Sandee, A. J. J. (1989). Production and consumption of tropical seagrass fields in eastern Indonesia measured with bell jars and microelectrodes. Neth. J. Sea Res. 23: 181-190

Mann, K. H. (1988). Production and use of detritus in various freshwater, estuarine and coastal marine ecosystems. Limnol. Oceanogr. 33: 910-930

Morgan, M. D., Kitting, C. L. (1984). Productivity and utilization of the seagrass Halodule wrightii and its attached epiphytes. Limnol. Oceanogr. 29: 1066-1076

Moriarty, D. J. W. (1976). Quantitative studies on bacteria and algae in the food of the mullet Mugil cephalus L. and the prawn Metapenaeus bennettae (Racek and Dall). J. exp. mar. Biol. Ecol. 22: 131-143

Moriarty, D. J. W. (1986). Measurement of bacterial growth

This article was presented by Dr G. F. Humphrey, Sydney, Australia rates in aquatic systems from rates of nucleic acid synthesis. Adv. microb. Ecol 9: 245-292

Moriarty, D. J. W. (1988). Accurate conversion factors for calculating bacterial growth rates from thymidine incorporation into DNA. elusive or illusive? Archiv Hydrobiol. Beih. Ergeb. Limnol. 31: 211-217

Moriarty, D. J. W (1989). Relationships of bacterial biomass and production to primary production in marine sediments. In: Hattori, T., Ishida, Y., Maruyama, Y., Morita, R. Y., Uchida, A. (eds.) Recent advances in microbial ecology. Japanese Scientific Societies Press, Tokyo, p. 349-354

Moriarty, D. J. W., Boon, P. I., Hansen, J. A., Hunt, W. G., Poiner, I. R., Pollard, P. C., Skyring, G. W., White, D. C. (1985). Microbial biomass and productivity in seagrass beds. Geomicrobiol. J. 4: 21-51

Moriarty, D. J. W., Iverson, R., Pollard, P. C. (1986). Exudation of organic carbon by the seagrass Halodule wrightii and its effect on bacterial growth in the sediment. J. exp. mar. Biol. Ecol. 96: 115-126

Moriarty, D. J. W., Pollard, P. C. (1981). DNA synthesis as a measure of bacterial productivity in seagrass sediments. Mar. Ecol. Prog. Ser. 5: 151-156

Moriarty, D. J. W., Pollard, P. C. (1982). Diel variation of bacterial productivity in seagrass (Zostera capricorni) beds measured by rate of thymidine incorporation into DNA. Mar. Biol. 72: 165-173

Odum, H. T., Hoskin, C. M. (1958). Comparative studies on the metabolism of marine waters. Publs Inst. mar Sci. Univ. Tex. 5: 16-46

Poiner, I. R., Staples, D. J., Kenyon, R. (1987). Seagrass communities of the Gulf of Carpentaria, Australia. Aust. J. mar Freshwat. Res. 38: 121-131

Pollard, P. C. (1987). Dialysis: a simple method of separating labelled bacterial DNA and tritiated thymidine from aquatic sediments. J. microbiol. Meth. 7: 91-101

Pollard, P. C., Moriarty, D. J. W. (1984). Validity of isotope dilution of tritiated thymidine during incorporation into DNA as an estimate of bacterial growth rates. Appl. environ. Microbiol. 48: 1076-1083

Roberts, D. G., Moriarty, D. J. W (1987). Lacunal gas discharge as a measure of productivity in the seagrasses Zostera capricornii, Cymodocea serrulata and Syringodium isoetifolium. Aquat. Bot. 28: 143-160

Robinson, J. D., Mann, K. H., Novitsky, J. A. (1982). Conversion of the particulate fraction of seaweed detritus to bacterial biomass. Limnol. Oceanogr 27 (6): 1072-1079

Strayer, D. (1988). On the limits to secondary production. Limnol. Oceanogr. 33: 1217-1220

Valiela, I. (1984). Marine ecological processes. SpringerVerlag, New York

Zieman, J. C., Wetzel, R. G. (1980). Productivity in seagrasses: methods and rates. In: Phillips, R. C., McRoy, C. P. (eds.) Handbook of seagrass biology: an ecosystem perspective. Garland STPM Press, New York, p. 87-116

Manuscript first received: August 24, 1989

Revised version accepted: December 1, 1989 